\title{
Long-term trajectory of some elasmobranch species off the Tuscany coasts (NW Mediterranean) from 50 years of catch data
}

\author{
ALESSANDRO LIGAS ${ }^{1}$, GIACOMO C. OSIO ${ }^{2}$, PAOLO SARTOR $^{1}$, MARIO SBRANA $^{1}$ \\ and STEFANO DE RANIERI ${ }^{1}$ \\ ${ }^{1}$ Centro Interuniversitario di Biologia Marina ed Ecologia Applicata “G. Bacci” (CIBM), viale N. Sauro 4, I-57128 \\ Livorno, Italy. E-mail: ligas@ cibm.it \\ ${ }^{2}$ EC Joint Research Centre (JRC), Institute for Protection and Security of the Citizen (IPSC), Maritime Affairs Unit G.04, \\ TP 051 Via Enrico Fermi 274921027 Ispra (Va), Italy
}

SUMMARY: The time series of elasmobranch catch rates off the Tuscany coasts (NW Mediterranean) were investigated by means of $\mathrm{min} / \mathrm{max}$ auto-correlation factor analysis in order to estimate variations in population abundance and evaluate the influence of environmental and anthropogenic factors. The analyses highlighted a general decreasing trend in the catch rates of sharks and skates from 1961 to the mid-1990s, mainly influenced by the increase in fishing effort. Since the 1990s, the EU Common Fishery Policy for the Mediterranean has promoted the reduction of fishing fleets through incentives to vessel demolition. The Porto S. Stefano trawl fleet has decreased by about $50 \%$, leading to a decrease in fishing effort which seemed to be the most relevant factor affecting the increasing trend shown by the catch rates of Galeus melastomus, Scyliorhinus canicula and skates from 1991 to 2009. The elasmobranch assemblage did not undergo major shifts but the weighted frequency of occurrence shows that elasmobranchs were more frequent in the past. Particular caution should be paid in interpreting the recent rebound of some species as an early sign of recovery: trawl survey data and landing data show that over the last 50 years elasmobranch fauna have undergone a drastic decline and that recent rebounds are still far from a recovery to historical levels.

Keywords: historic data, trawling, auto-correlation factor analysis, cartilaginous fish, Mediterranean Sea.

RESUMEN: Trayectoria a largo plazo de algunas especies de Elasmobranquios en los mares de Toscana (MediterRáneo noroccidental) a tRAVÉS DE 50 años DE DATOS DE CAPtura. - Se investigaron las series históricas de datos de captura de algunas especies de Elasmobranquios en los mares de Toscana (Mediterráneo noroccidental), por medio del análisis de auto-correlación factorial MAFA, con el fin de evaluar las variaciones en la abundancia de poblaciones y la influencia de factores ambientales y antropogénicos. Los análisis permitieron poner en relieve una tendencia a la disminución, a partir de 1961 hasta la mitad de los años 1990, de las tasas de captura de las especies de tiburones y rayas demersales. Esta disminución parece ser debida principalmente al aumento del esfuerzo pesquero. Sin embargo, desde 1990 capacidad y actividad pesquera mostraron una tendencia a la disminución, como resultado de la Política Pesquera Común de la UE para el Mediterráneo. La flota de arrastre de Porto Santo Stefano disminuyó en un 50\%; esta reducción parece ser el factor más importante que produjo un aumento en los indices de abundancia relativa de Galeus melastomus, Scyliorhinus canicula y de las rayas, desde 1991 a 2009. Sin embargo la composición en especies de los Elasmobranquios no ha mostrado evidentes cambios en el tiempo, a pesar de muchas especies que han sufrido una disminución en la frecuencia de occurrencia. Por lo tanto, la interpretación de estos resultados como señal de recuperación de las poblaciones de elasmobranquios, necesita de una precaución especial. De hecho durante los últimos 50 años la fauna de elasmobranquios en el Mediterráneo ha sufrido una drástica reducción y todavía no se está observando ninguna considerable señal de recuperación.

Parablas clave: datos históricos, arrastre, análisis del factor de auto-correlación, peces cartilaginosos, mar Mediterráneo. 


\section{INTRODUCTION}

For thousands of years fishing activities has fundamentally altered marine ecosystems. Elasmobranchs appear to be particularly vulnerable to fishing exploitation: their biological characteristics, such as low fertility, low growth rate and late sexual maturity, make them vulnerable to drastic increases in mortality rates (Stevens et al. 2000, Baum et al. 2003).

Many elasmobranchs are increasingly threatened with extinction as a result of human activities, and in many parts of the world these populations have been greatly reduced (Cavanagh and Gibson 2007, Ferretti et al. 2008). Sharks and rays play an important ecological role in demersal communities: many species are predators at or near the top of marine food chains. Recent research suggests that the absence of sharks can indirectly alter predation pressure on different fish species via behavioural responses of meso-consumers released from predator intimidation and shark declines might have stronger ecological consequences than has been previously recognized (Frid et al. 2008). The removal of certain species of predators reduces environmental heterogeneity; therefore, elasmobranch overexploitation can have a detrimental effect on the whole ecosystem by disturbing the complex equilibrium that these predators provide (Gouraguine et al. 2011). For these reasons, understanding the ecological role, distribution, and life histories of elasmobranchs is considered as a fundamental step towards the preservation of marine biodiversity, and the impact of fishing on elasmobranch stocks and the consequences of their decline on the ecosystem are currently raising considerable international concern (Stevens et al. 2000, Myers and Worm 2003, Ferretti et al. 2010).

This scenario also applies to the Mediterranean Sea, where intense fishing activity is exerted from the continental shelf and upper slope down to $800 \mathrm{~m}$ depth. In multi-species fisheries, such as the Mediterranean trawl fisheries, elasmobranchs make up a significant proportion of the by-catch, and are at present a minor part of landings (Damalas and Vassilopoulou 2011, Maynou et al. 2011, Sartor 2011). Consequently, shark depletion often goes unnoticed and extraction may continue for many years, as the fishery is sustained by the more productive target species. In addition, given the mainly artisanal character of the Mediterranean fisheries, as well as the relatively low economic value of elasmobranchs, catches are rarely reported adequately (Ferretti et al. 2008).

Although previous studies carried out in different areas of the Mediterranean Sea highlighted that shark species diversity and biomass have decreased in the last century due to fishing pressure (Ferretti et al. 2005, Ferretti et al. 2008, Dell'Apa et al. 2012), the depletion of the elasmobranch community in the whole Mediterranean region could be largely underestimated and requires an immediate large-scale assessment (Ferretti et al. 2008). The importance of using historical data to prevent misidentifying of baselines of abundance of marine resources is clear (Cardinale et al. 2011); however, this comes with the price that historical data most often have lower resolution and higher uncertainty. Therefore, the compromise between accuracy and short time span versus low resolution but long time span needs to be carefully weighed. The aim of this study is to assess the temporal variation of some elasmobranch populations in a Mediterranean area in the past 50 years using commercial landings and trawl survey data. Additionally, environmental variables and fishing effort indices were taken into account to evaluate their influence on elasmobranch population dynamics.

\section{MATERIALS AND METHODS}

The study was performed in western Italian waters, off the Tuscany Region, in the eastern Ligurian and northern Tyrrhenian Sea (NW Mediterranean) (Fig. 1). This area is semi-enclosed between islands (Corsica, Sardinia and Elba) and the mainland (Italy), and separated from the rest of the western basin by a channel of moderate depth. It can therefore be considered a distinct entity within the central-western Mediterranean basin. The circulation in the Tyrrhenian Sea is organized in a series of cyclonic (counter-clockwise) and anticyclonic (clockwise) gyres determined by the wind: three main cold water gyres (two cyclonic and one anticyclonic) have been detected. They undergo significant seasonal change, particularly the central anticyclonic gyre that spreads over most of the basin in spring and summer and almost disappears in autumn and winter. The intermediate (LIW) and deep waters have a constant temperature $\left(12.8^{\circ} \mathrm{C}-13.0^{\circ} \mathrm{C}\right)$ (Nezlin et al. 2004, Gasparini et al. 2005). Mixing of surface and deep layer from wind-driven turbulence enriches the upper layer with nutrients, giving the eastern Ligurian and northern Tyrrhenian Sea a relatively high concentration of nutrients within the Mediterranean basin) (Nezlin et al. 2004).

Three data sets were collected and analysed. The first came from the Italian official fisheries statistics collected and provided by the Italian Central Institute of Statistics (ISTAT) and the Institute of Economic Research in Fishery and Aquaculture (IREPA). Within this dataset only those referring to the Tuscany Region were retained from 1961 to 2009 for trawl fishing capacity and for landings of "shark-like elasmobranchs" (hereafter "sharks") and "skates". According to the original ISTAT definition, the shark category should be mainly composed of Mustelus spp., Squalus spp., Galeus melastomus and Scyliorhynus canicula. However, this represents a broad category of elasmobranchs and probably includes more species, since it is not possible to accurately estimate the species composition. In this case the resolution of the series at species level is low but the use of the ISTAT-IREPA series greatly extends the time series and the possibility of identifying some baseline prior to the extensive trawling ef- 


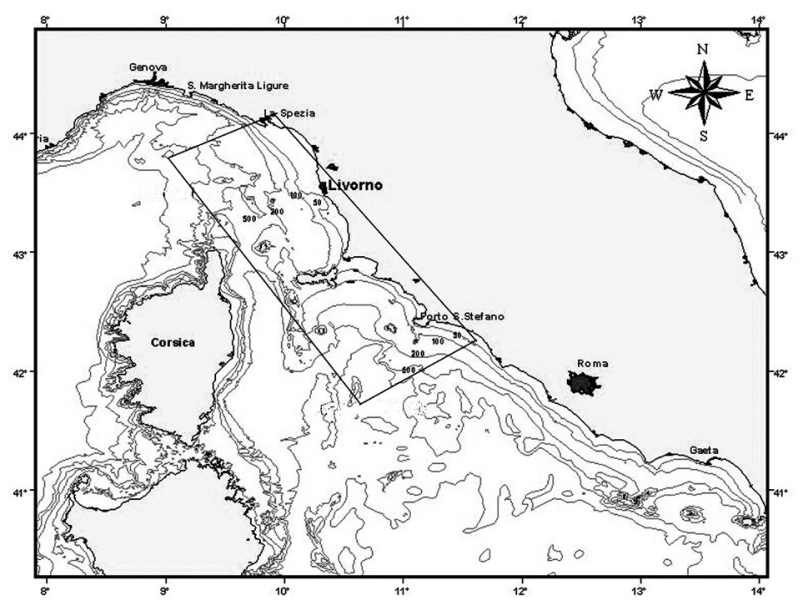

FIG. 1. - Study area, eastern Ligurian and northern Tyrrhenian Sea (NW Mediterranean). The fishing grounds exploited by the Tuscan trawl fleet are enclosed by the rectangle.

fort development of the 1980s (Cardinale et al. 2011). Yearly catch rates $(\mathrm{kg} / \mathrm{year} / \mathrm{vessel})$ were calculated for each group. A second data set consisted of the trawl landings collected by direct sampling at the fish auction of Porto S. Stefano, southern Tuscany from 1991 to 2009. This port was chosen because of the presence of a major fleet specialized in demersal trawl fishery (see Ligas et al. 2010). Monthly catch rates (kg/day/ vessel) were calculated for the most relevant species landed in this period: the blackmouth catshark (Galeus melastomus), the small-spotted catshark (Scyliorhinus canicula), and the commercial category "skates", mainly comprising the thornback ray (Raja clavata) and the starry ray (Raja asterias). Other elasmobranch species did not have a sufficient detection level for the analysis performed here.

The third data set consisted of data collected through four different trawl surveys: Matta (19571958, 16 tows), Merlo (1972-1974, 79 tows), Grund (1994-2006, 443 tows), and Medits (1994-2006, 464 tows) (see Sartor 2011 for technical specifications on the surveys). The frequency of occurrence of elasmobranchs was weighted by the number of hauls of each survey after pooling all hauls across years in each survey. Comparison of weighted frequency of occurrence was performed by depth and the surveys were split into a depth range of 10-280 m (Matta/Grund/Medits) and 280-756 m (Merlo/Grund/Medits). This exercise was only aimed at identifying a change in the elasmobranch assemblage and not at estimating abundance trends.

To investigate the effect of environmental drivers on the temporal variation in catch rates, a suite of explanatory variables that may potentially affect the production, recruitment and growth of species was selected: sea surface temperature $\left(\mathrm{SST},{ }^{\circ} \mathrm{C}\right)$, scalar wind $(\mathrm{m} / \mathrm{s})$ (http://icoads.noaa.gov/index.shtml) and the western Mediterranean oscillation index (WeMO) (see MartinVide and Lopez-Bustins 2006; http://www.ub.edu/gc/ English/wemo.htm).
In the Ligurian-Tyrrhenian basin, atmospheric factors such as SST and wind speed are known to affect primary production, deepening the mixed layer, enhancing the storage of nutrients, and thus resulting in higher phytoplankton production in deeper layers (Nezlin et al. 2004). In addition, Bartolino et al. (2008) hypothesized that summer anomalous oceanographic scenarios, in terms of SST and wind circulation, could affect water stratification and modify gyres and water circulation systems. Therefore, time series of SST and scalar wind averaged over the whole eastern Ligurian and northern Tyrrhenian area were chosen as the best available surrogate in the absence of complete series of data concerning water column physic-chemical characteristics in the deeper layers.

In order to estimate the impact of fishing pressure on the temporal variation of landings, some indices of fishing activity and capacity were derived from the Porto S. Stefano trawl fleet landings: the total number of days at sea performed per month, and the mean gross tonnage (GRT) and mean engine power $(\mathrm{kW})$ per month. The time series of the number of vessels ( $>12$ $\mathrm{m}$ Overall Length, OL) and total engine power (kW) of the trawl fleet in Tuscany was used as an explanatory variable to analyse the 1961-2009 landings time series.

Catch rate analysis relies upon the assumption that catchability is constant over time, but this assumption does not hold if technological creeping and changes in fleet characteristics and fishing strategies affect the catching efficiency (Lindebo et al. 2007, van Oostenbrugge et al. 2008). Therefore, when analysing landings data over long time periods, changes in fishing power or catchability should be carefully considered since the bias introduced by such factors can be great (Bishop 2006). Improved catching efficiency (or technological creep) of a fleet is usually positively related to the increase in skipper skills, investments in auxiliary equipment and more efficient gears and materials, replacement of old vessels by new ones, upgraded engines, etc. (Lindebo et al. 2007, van Oostenbrugge et al. 2008, Cardinale et al. 2009). Fishing power growth has been estimated in different trawl fisheries and can range between 1.6 and $2.8 \%$ per year for beam trawls targeting sole and plaice in the North Sea (Rijnsdorp et al. 2006), 0.6 and $3.1 \%$ for prawn fisheries in Australia (O'Neill and Leigh 2007) and up to 10\% for Australian northern prawn fisheries (Ellis and Wang 2006). In the Mediterranean there are no correction factors taking into account this change, so it was decided to use an approach similar to that provided by Cardinale et al. (2009) to correct the two data sets. This approach consists in simulating different scenarios of theoretical increase in fishing power ranging from 0 (fishing power considered constant over time) to $2 \%$ constant increase per year. In the case of a simulated fishing power increase of $1 \%$ per year, the corrected catch rate is:

$$
\text { catch_rate } \text { corrected }=\frac{\text { catch_rate }_{\text {uncorrected }}}{1.01^{\left(\text {Year }_{\text {curent }}-\text { Year }_{\text {initial }}\right)}}
$$


Analytically, both the response and explanatory time series were explored by means of the auto- and cross-correlation functions. The auto-correlation function gives an indication of the amount of association between variable $\mathrm{Y}_{\mathrm{t}}$ and $\mathrm{Y}_{\mathrm{t}-\mathrm{k}}$, where the time lag $\mathrm{k}$ takes the values 1, 2, 3, etc. (Zuur et al. 2007). Thus, this function is used to highlight the presence of cyclic patterns in time series. Formulated differently, the auto-correlation with a time lag of $\mathrm{k}$ years represents the overall association between values that are separated by $\mathrm{k}$ time points. The cross-correlation function shows the relationship between two variables $\mathrm{Y}$ and $\mathrm{X}$ at different time lags $\left(\mathrm{Y}_{\mathrm{t}}\right.$ and $\left.\mathrm{X}_{\mathrm{t}-\mathrm{k}}\right)$. Therefore, this tool can be used to determine whether there is a (linear) relationship between two variables (Zuur et al. 2007). In time series analysis, the use of significantly correlated variables should be avoided. The confidence intervals for both auto- and cross-correlations are obtained from $\pm 2 / \sqrt{ } \mathrm{n}$, where $\mathrm{n}$ is the length of a time series.

Cyclic or seasonal patterns were removed from the data through the seasonal decomposition by locally weighted scatterplot smoothing (Loess smoothing); this method uses repeated Loess smoothing to divide a variable $Y_{t}$ into three components: the trend, the seasonal effect, and the remainder (Zuur et al. 2007).

The smooth patterns of data obtained with the seasonal decomposition by Loess smoothing were further analysed through $\mathrm{min} / \mathrm{max}$ auto-correlation factor analysis (MAFA) (Solow 1994) using the software package Brodgar 2.9.1 (www.brodgar.com, www. highstat.com). MAFA can be described as a type of principal component analysis (PCA): while in PCA the first axis explains most variance, in MAFA the trend has the highest auto-correlation with lag 1 . The underlying idea is that a trend is associated with high autocorrelation with time lag 1 . Therefore, the first MAFA axis represents the trend, or the main underlying pattern in the data. This axis can also be seen as an index function or smoothing curve. Cross-correlations (canonical correlations) between the variables (both response and explanatory variables) and the trends were computed to evaluate the significance of the relationship between the variables and the trends. The mathematics behind MAFA is described in Solow (1994). The underlying formula is, similarly to PCA:

$$
\mathrm{m}_{\mathrm{t}}=\mathrm{A} \times \mathrm{y}_{\mathrm{t}}
$$

where $m_{t}$ represents the N MAFA axes at time $t, y_{t}$ contains the $\mathrm{N}$ variables of the data set measured at time $t$ and $A$ is a matrix of dimension $N \times N$ containing the canonical correlations. In matrix notation, this can be written as:

\section{$\mathrm{M}=\mathrm{Y} \times \mathrm{A}$}

where $\mathrm{M}$ is a t-by- $\mathrm{N}$ matrix containing the MAFA axes, and $\mathrm{Y}$ the matrix containing the time series. The MAFA calculations involve a PCA on centred data

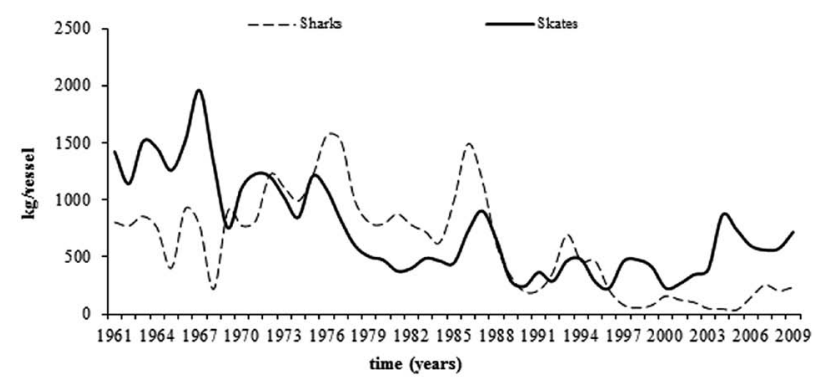

FIG. 2. - Shark and skate catch rates (kg/year/vessel) in the Tuscany Region in 1961-2009 (Data source ISTAT, 1961-2001, IREPA, 2002-2009).

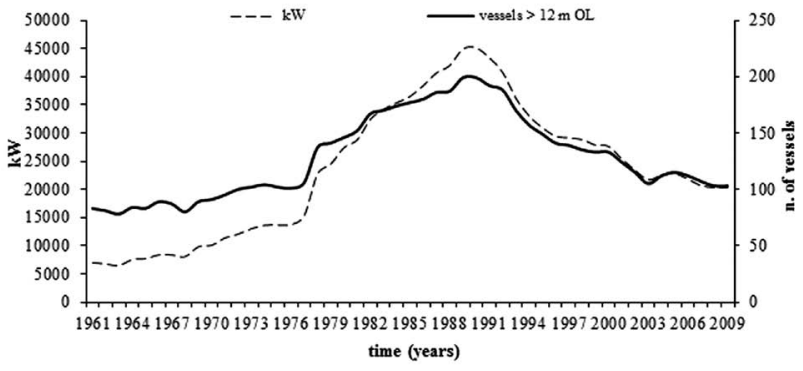

FIG. 3. - 1961-2009 data set: time series plots of total engine power $(\mathrm{kW})$ and number of trawl vessels $>12 \mathrm{~m}$ overall length.

$\mathrm{Y}$, followed by a first differencing on the principal components, and a second PCA on these differenced components. As a result, the MAFA axes are mutually uncorrelated with unit variance, and the MAFA axes have decreasing auto-correlation with time lag 1.

\section{RESULTS}

The catch rate time series of sharks and skates obtained from the Italian official fisheries statistics for the period 1961-2009 seem to follow a general decreasing pattern (Fig. 2), while the total engine power (kW) and the number of vessels increased until 1990 and started
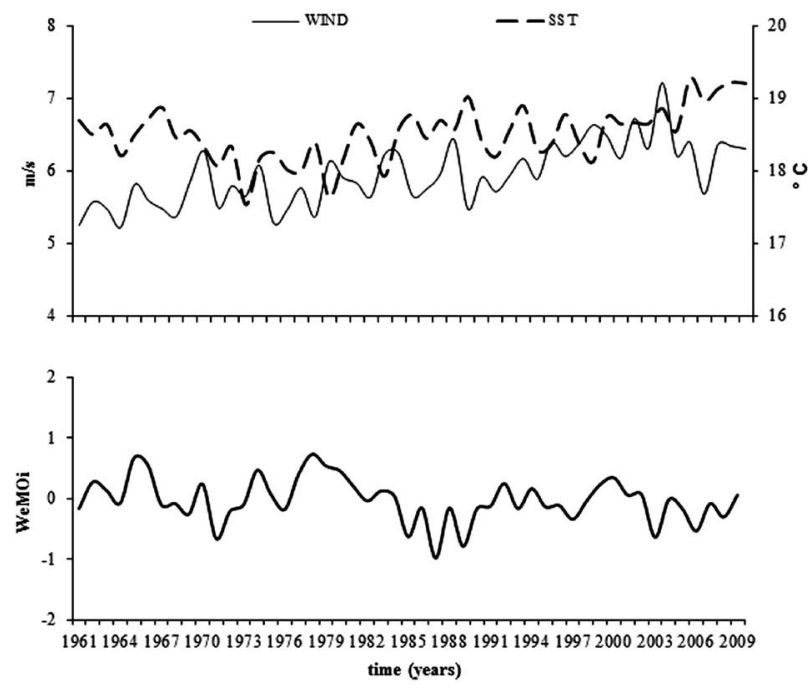

FIG. 4. - Time series plots of mean annual sea surface temperature (SST), scalar wind (Wind) and WeMO index from 1961 to 2009. 


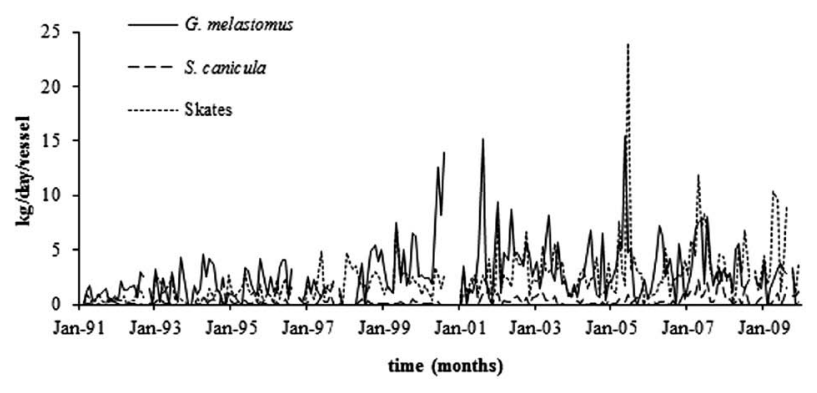

FIG. 5. - Porto S. Stefano data set: time series plots of monthly catch rates (kg/day/vessel) from 1991 to 2009.

declining in the following period (Fig. 3). SST, wind and WeMOi showed oscillating behaviours (Fig. 4), but no significant auto-correlation was found, so the time series were analysed without applying smoothing by means of seasonal decomposition (Loess smoothing). Among the explanatory variables, a significant cross-correlation (0.98) was highlighted between the time series of the number of vessels and that of the engine power $(\mathrm{kW})$. Therefore, only the time series of the number of vessels was used as a fishing capacity variable; all the environmental and response variables were included in the data set analysed by means of MAFA.

The plot of the monthly catch rates (kg/day/vessel) of the Porto S. Stefano trawl fleet is shown in Figure 5. The fishing activity (total days at sea per month) follows a general decreasing pattern, although an increase is detectable since 2002, while GRT and engine power $(\mathrm{kW})$ increased until the 1990s and then showed a decreasing pattern (Fig. 6). A cyclical component with time lag 12 is present in both the response variables and the environmental factors, so they were deseasonalized by Loess smoothing to remove this component. The data exploration performed by means of crosscorrelation function highlighted that SST and the scalar

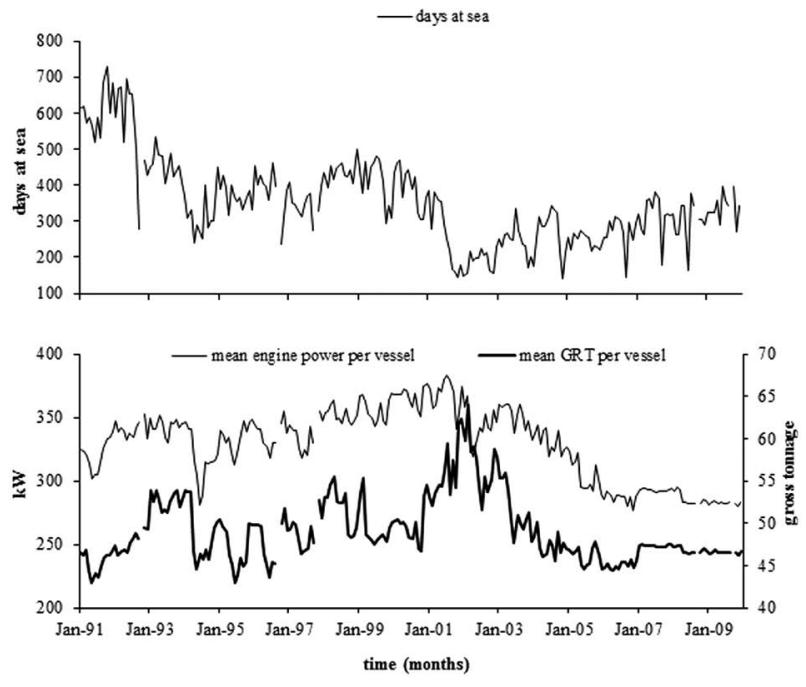

FIG. 6. - Time series plots of the days at sea per month performed by the Porto S. Stefano trawl fleet, and of the mean gross tonnage $($ GRT) and engine power $(\mathrm{kW})$ per vessel.
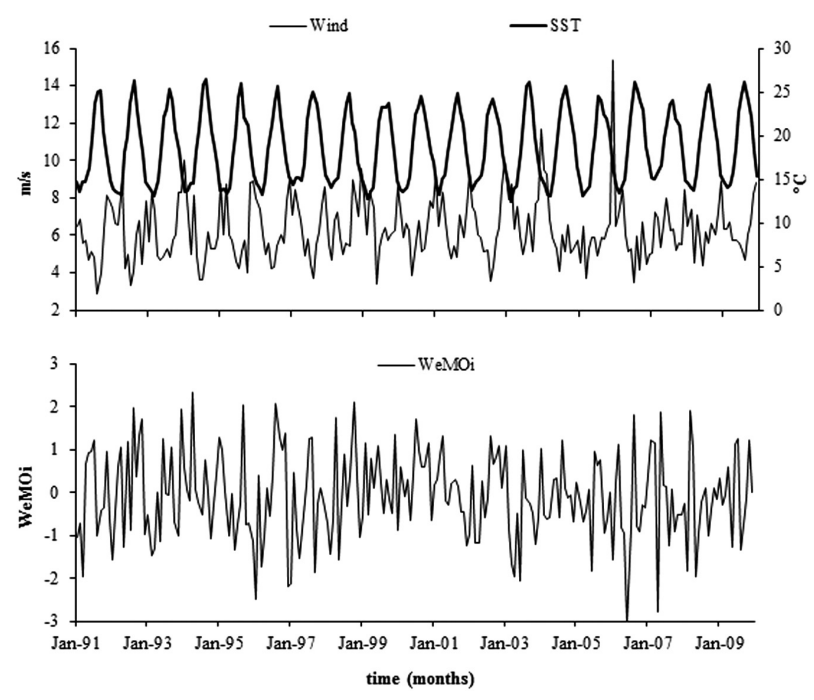

FIG. 7. - Time series plots of mean monthly sea surface temperature (SST), scalar wind (Wind) and WeMO index from 1991 to 2009.

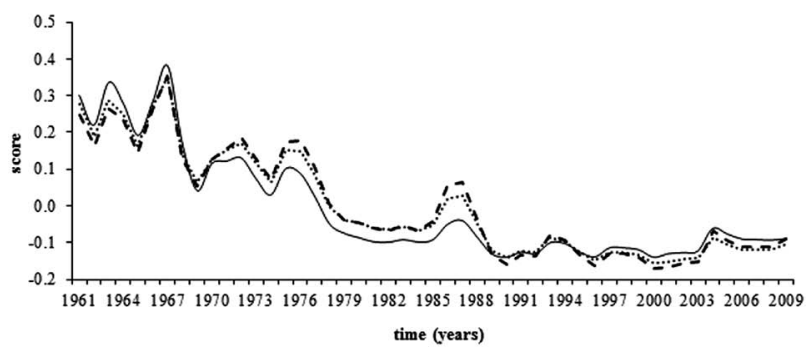

FIG. 8. - 1961-2008 data set: common smooth pattern computed by means of MAFA from the 1961-2009 ISTA/IREPA data set; technological creep $0 \%$ (solid line), 1\% (dashed line), 2\% (dotted line).

wind are significantly correlated $(-0.61)$, as are GRT and engine power (0.68). Therefore, it was decided to use only the SST, the WeMOi index, days at sea and GRT as explanatory variables in the analyses. No significant cross-correlations were highlighted among the response variables.

For the ISTAT/IREPA fisheries data from 1961 to 2009, a continuous decreasing pattern, with a drastic reduction in the commercial yields, was computed by MAFA (Fig. 8); however, the pattern seemed to invert the tendency from 2000 onwards. A very high autocorrelation (0.91) with time lag 1 was associated with

TABLE 1. - 1961-2009 data set: cross-correlations between variables and MAFA trend for the three technological creep simulations $(0 \%$, $1 \%, 2 \%$ ). Response variables: sharks and skates $\mathrm{kg} / \mathrm{year} / \mathrm{vessel}$ time series. Explanatory variables: SST, sea surface temperature $\left({ }^{\circ} \mathrm{C}\right)$; WeMOi, WeMO index; wind, scalar wind $(\mathrm{m} / \mathrm{s}) ; \mathrm{n}$. vessels, number of vessels $>12$ m overall length. Significant correlations are in bold $(\mathrm{p}<0.05)$.

\begin{tabular}{llccc}
\hline & & & & \\
& & & & \\
\hline Response variables & creep 1\% & creep 2\% \\
& Sharks & $\mathbf{0 . 7 6}$ & $\mathbf{0 . 7 4}$ & $\mathbf{0 . 7 7}$ \\
Explanatory variables & Skates & $\mathbf{0 . 9 9}$ & $\mathbf{0 . 9 7}$ & $\mathbf{0 . 9 8}$ \\
& SST & -0.11 & -0.26 & -0.26 \\
& WeMOi & 0.18 & 0.14 & 0.16 \\
& n. vessels & $\mathbf{- 0 . 7 4}$ & $\mathbf{- 0 . 6 1}$ & $\mathbf{- 0 . 6 2}$ \\
\hline
\end{tabular}




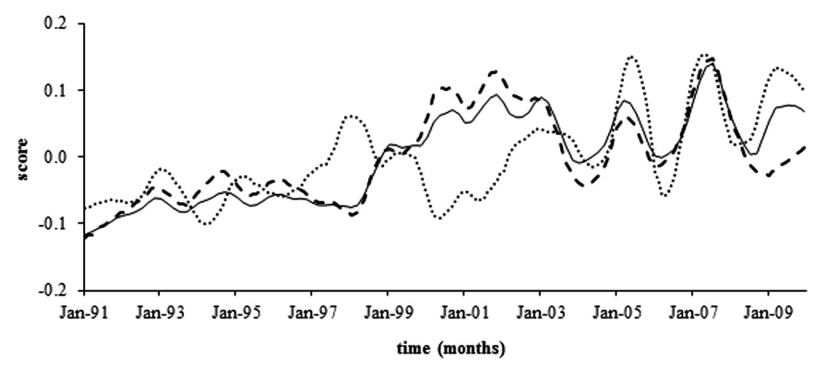

FIG. 9. - Porto S. Stefano data set: common smooth pattern computed by $\mathrm{min} / \mathrm{max}$ auto-correlation factor analysis from the 1991-2009 Porto S. Stefano trawl fleet data set; technological creep 0\% (solid line), $1 \%$ (dashed line), $2 \%$ (dotted line).

TABle 2. - Porto S. Stefano data set: cross-correlations between variables and MAFA trend for the three technological creep simulations $(0 \%, 1 \%, 2 \%)$. Response variables: catch rates $(\mathrm{kg} /$ day $/ \mathrm{vessel})$ time series of G. melastomus, S. canicula and skates. Explanatory variables: SST, sea surface temperature $\left({ }^{\circ} \mathrm{C}\right)$; WeMOi, WeMO index; Days at sea, number of days at sea per month; GRT, mean gross tonnage. Significant correlations are in bold $(\mathrm{p}<0.05)$.

\begin{tabular}{llccc}
\hline & & \multicolumn{3}{c}{ creep 0\% creep 1\% creep 2\% } \\
\hline Response variables & G. melastomus & $\mathbf{0 . 9 0}$ & $\mathbf{0 . 8 9}$ & $\mathbf{0 . 8 9}$ \\
& S. canicula & $\mathbf{0 . 7 6}$ & $\mathbf{0 . 7 1}$ & $\mathbf{0 . 6 1}$ \\
& Skates & $\mathbf{0 . 7 8}$ & $\mathbf{0 . 6 5}$ & $\mathbf{0 . 9 2}$ \\
Explanatory variables & SST & 0.39 & 0.17 & 0.07 \\
& WeMOi & 0.04 & 0.14 & -0.26 \\
& Days at sea & $\mathbf{- 0 . 6 7}$ & $\mathbf{- 0 . 6 1}$ & $\mathbf{- 0 . 5 6}$ \\
& GRT & 0.22 & 0.38 & -0.15 \\
\hline
\end{tabular}

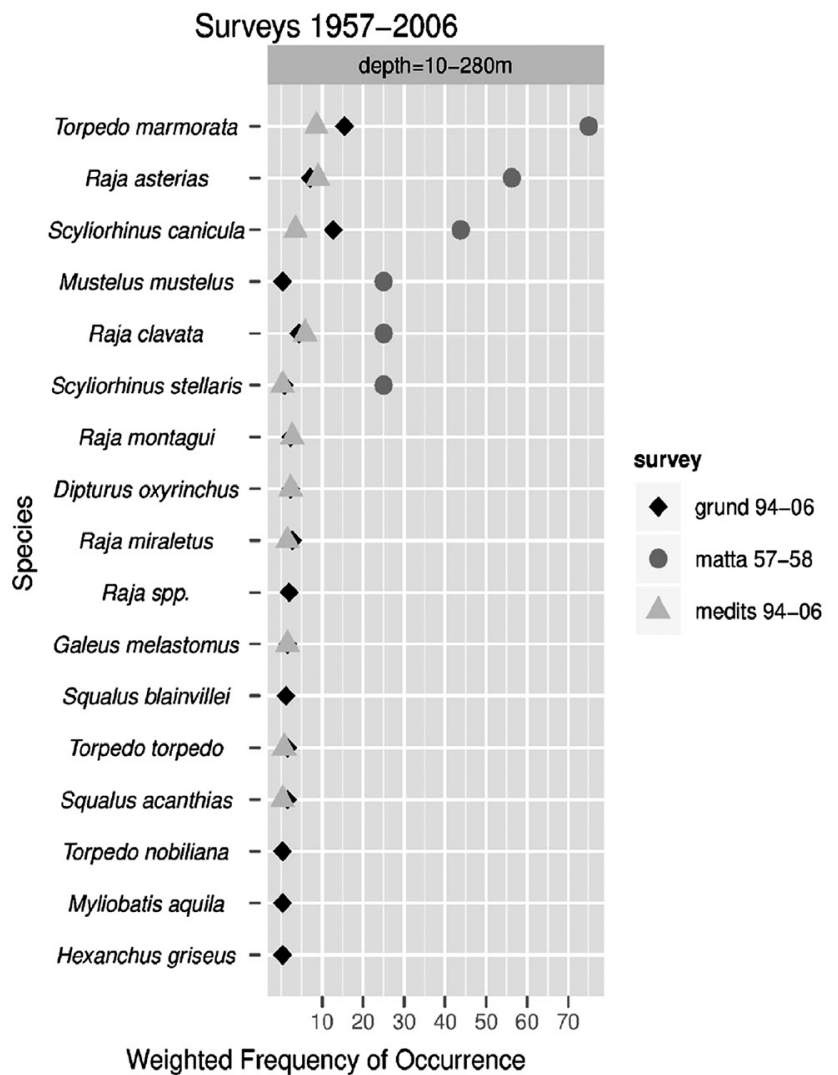

the estimated pattern. Regarding the explanatory variables, the number of vessels and the scalar wind were significantly and negatively associated with the smooth pattern (Table 1): this means that the decreasing pattern of landing rates was related to the increase in fishing effort and wind circulation. While they lowered the corrected catch rates in the recent years, the corrections applied to simulate the fishing power increase (from $0 \%$ to $2 \%$ per year) did not produce appreciable changes in the analysis.

On the other hand, the common smooth pattern extracted by means of MAFA from the Porto S. Stefano landing time series described a slightly increasing pattern (auto-correlation at time $\operatorname{lag}_{1}=0.99$ ) (Fig. 9). The smooth pattern was significantly correlated with the three response variables (Table 2); among the explanatory variables, only fishing effort was correlated with the common pattern. The negative correlation between pattern and fishing effort suggests that the increase in catch rates was influenced by the decrease in fishing activity. Again, in this case the corrections simulating fishing power increase (from $0 \%$ to $2 \%$ ) did not substantially modify the results obtained from this data set.

The comparison among trawl surveys (Fig. 10) showed a general and substantial reduction in the frequency of occurrence over time, with the oldest surveys having the highest frequencies for the most common species. In the 10-280 $\mathrm{m}$ depth range, the top ranking

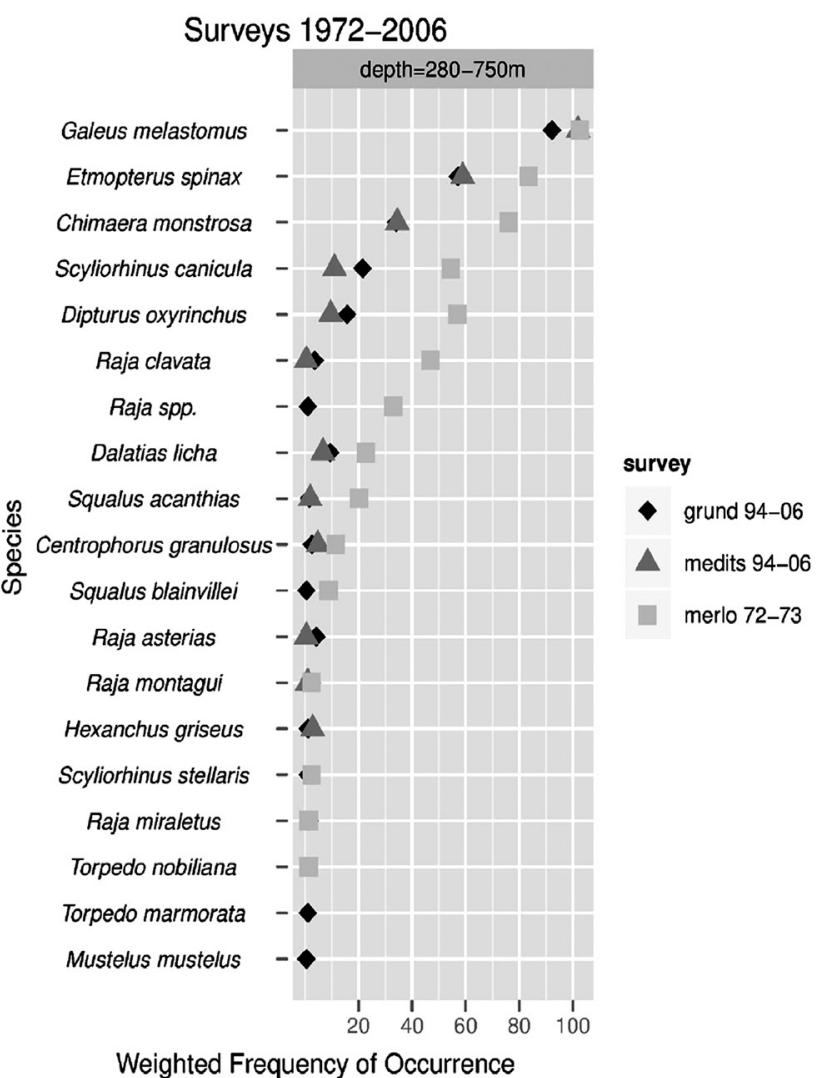

FIG. 10. - Elasmobranch species average frequency of occurrence by depth range (10-280 m; 280-750 m) for the Matta, Merlo, Grund and Medits trawl surveys carried out between 1957 and 2006. 
species are the same from Matta survey to Medits. A similar situation is found in the $280-750 \mathrm{~m}$ range, although the species are different. Therefore, while the frequency of occurrence has decreased in the last 50 years, the species composition of the elasmobranch assemblages seems stable since 1957 for the shallow area $(<280 \mathrm{~m})$ and since 1972 for the deeper area $(>280 \mathrm{~m})$.

\section{DISCUSSION}

Since ecosystems have changed over time due to both anthropogenic and natural factors, fisheries management should not be based only on studies of recent populations. Though long time series of data have been collected in the Atlantic and North Sea (e.g. many fish stocks in the North Atlantic, Rijnsdorp et al. 2006), fisheries time series in the Mediterranean usually cover the last few decades only, and current management advice is based on data starting at best in the early 1990s (see Cardinale et al. 2010). Therefore, the availability of 50-year series of fisheries data should be regarded as an almost unique opportunity to counteract a shifting baseline in fisheries management.

The present study found that, among the environmental variables, the wind circulation only showed a negative significant correlation with the decreasing pattern of elasmobranch abundance computed from the Italian official fisheries data set in the period 19612009. Atmospheric and sea surface variables-which are available in long and complete time series at global and local scale, while information on the deep-sea parameters is still scarce and scattered in both time and space-have been used in several studies, and have proved their influence on the demersal and benthic communities (Bartolino et al. 2008, Cartes et al. 2009, Ligas et al. 2010). Benthic communities depend on the flux and the arrival of organic matter from the upper layers, so the atmospheric phenomena which influence the primary production and productivity in the shallower waters and in the upper layers of the open sea might alter trophic webs and species abundance in the benthic habitats (Company et al. 2008). According to the significant relationship between the increase in wind circulation and the elasmobranchs landings in the period 1961-2009, one could hypothesize an alteration of the organic fluxes that normally maintain the deepwater benthic communities in the northern Tyrrhenian and eastern Ligurian Seas, with resulting effects on the abundance of demersal elasmobranch populations.

As stated above, the analysis of the 1961-2009 data sets highlighted the presence of a clear decreasing trend in the elasmobranch catch rates. This scenario fit almost neatly with the whole Italian elasmobranch landings described by Dell'Apa et al. (2012), which showed a fairly constant decrease in elasmobranch LPUE in Italy.

However, the pattern of elasmobranch landings in Tuscany seemed to show an inversion from 2000 onwards. This inversion is confirmed by the increasing pattern in catch rates computed from the second data set: the catch rates by the Porto S. Stefano trawl fleet (1991-2009). The available evidence suggests that the fishing pressure could have influenced these patterns. The increase in fishing capacity (number of vessels and engine power) until the 1980s was coupled with the decreasing pattern of the landings per unit of effort. The response of elasmobranch populations to the reduction in fishing pressure could be represented by the increasing pattern in catch rates computed from the 1991-2009 data set, which was coupled with the decrease in the fishing activity (days at sea per month). The reduction of the fishing fleets since the late 1990s was a consequence of the Common Fishery Policy for the Mediterranean, which subsidized the demolition of older vessels and the construction of newer ones with theoretically less fishing capacity. As a matter of fact, the trawl fleet of Porto S. Stefano underwent a decrease during the study period, from 55 vessels in 1994 to 25 in the last few years (Ligas et al. 2010). In addition, the mean size (GRT) and the mean engine power of the trawl vessels of the same fleet have followed a decreasing pattern, mainly in response to the global crisis which has influenced fisheries and to the sharp increase in fuel costs.

The increasing pattern shown by the elasmobranch species under investigation is confirmed by the analysis of fishery-independent data (experimental trawl surveys), which show increasing patterns in the abundance of Galeus melastomus, Etmopterus spinax, and Dipturus oxyrinchus in the Tyrrhenian and Ligurian Seas in the period 1985-2006 (Baino et al. 2007). However, when data prior to 1994 (Matta and Merlo surveys) are included, it appears, with the exception of Galeus melastomus, that most species are well below their abundance levels in the 1950s or 1970s.

In the absence of direct technological creep estimations for Mediterranean fisheries, different correction factors (from $0 \%$ to $2 \%$ per year) were tested to simulate the fishing power increase in the present study. These correction factors did not produce appreciable changes in the results; a $2 \%$ yearly increase might be an underestimate of the real efficiency increase of motor trawlers over the past 50 years, but unfortunately no such estimates are available at the moment. Furthermore, the reduction in mean engine power and GRT of the Porto S. Stefano trawl fleet from 2001 could have balanced the fishing power increase due to the improvement in skipper skills, auxiliary equipment, etc.

Though the increase in landings since the late 1990s should be carefully interpreted as an early response of some elasmobranch species to the reduction in fishing pressure, the current abundance of elasmobranch populations in the Tuscany waters obtained from the catch rates observed in recent years is far from the levels of the early 1960s. The catch rates at the beginning of the study period were about $1 \mathrm{t}$ per year per vessel for skates, and $500 \mathrm{~kg}$ per year per vessel for sharks, while they have been less than $500 \mathrm{~kg}$ per year per vessel for 
skates and $200 \mathrm{~kg}$ for sharks in recent years. The catch rates from Porto S. Stefano (1991-2009) show fairly low values even in the most recent years, in the range of 3 to $5 \mathrm{~kg} / \mathrm{day} / \mathrm{vessel}$ for skates, and 1 to $2 \mathrm{~kg} / \mathrm{day} /$ vessel for G. melastomus and Scyliorhinus canicula, which are in agreement with the ISTAT/IREPA data if a mean fishing activity of 170-180 days per year is considered (Cardinale et al. 2010).

Further confirmation of this pattern comes from the patterns in frequency of occurrence and relative abundance reconstructed from experimental trawl surveys in the Mediterranean over the period 1975-2009, which show a significant decline in $S$. canicula catch rates of $87.1 \%$ over 36 years, while a non-significant pattern was evidenced for skates. A slight increasing trend has been observed in the last three years (Sartor 2011).

The analysis of the ISTAT/IREPA series looks at the total catch of elasmobranchs and skates and clearly describes a decline, which is strongly supported by the decline in frequencies of occurrence in trawl surveys. Whether the decline is associated with a shift in assemblage or not, which is the case here, does not hamper the result. This is often the case for species that have high aggregation levels in the landings statistics (Ferretti et al. 2008) and it is scientifically acceptable to investigate broad group trends (Maynou et al. 2011). The most recent increase from the Porto S. Stefano series is driven by the most resilient and productive elasmobranchs and skates, which were already the most common in the past 60-50 years.

Once overfished, many shark populations would take several decades to recover (Stevens et al. 2000). Most of the most abundantly landed species in the early $20^{\text {th }}$ century, such as Squalus acanthias, Mustelus spp. and Squatina squatina, appear to be the least occurring today (Fortibuoni et al. 2010, Sartor 2011). These considerations are also confirmed by the absence of these species in the landings by the Porto S. Stefano trawl fleet.

The Mediterranean elasmobranch community of the coastal zones showed a drastic decrease in species diversity as well as a decline in population abundance (Ferretti et al. 2005) and the results presented here, despite the recent rebound of some species, are consistent with this picture.

Exceptions to this general situation are the populations of G. melastomus, S. canicula and skates (Raja asterias and $R$. clavata), which are among elasmobranch species that are most productive and resilient to fishing pressure (Cavanagh and Gibson 2007); these are the only species that have shown some signals of recovery in the waters of Tuscany. The current analysis shows that the current reduction in fishing effort could have some beneficial effects for highly productive elasmobranchs, but it also shows that effort needs to be reduced more if we are to detect a recovery of less productive species.

Further fisheries management measures for fishing pressure reduction should be put in place, as highlight- ed by STECF Expert Working Group from the stock assessment on demersal resources in the Mediterranean (Cardinale et al. 2011). While elasmobranchs should benefit from a further reduction in fishing effort, they are at the same time non-targeted (making a negligible part of fisherman intake) and resilient species with high post-capture survival rates. Therefore, through awareness campaigns and disincentives to fishermen, fishing mortality could be reduced with measures aiming at reducing elasmobranch species landings. Additionally, high values of elasmobranch biomass and diversity have been observed in the Balearic Islands (Gouraguine et al. 2011, Ordines et al. 2011), and in areas spanning from the Corsica and Sardinia Islands to the Italian peninsula; therefore, the implementation of specific conservation interventions, such as corridors of protected areas, would contribute to the recovery of elasmobranch populations in western Italian waters, in the areas of the Aegean Sea rich in elasmobranch diversity (Damalas and Vassilopoulou 2011) and on the Mediterranean coasts of North Africa (UNEP-MAP RAC/SPA 2005, Ordines et al. 2011). Up to now no specific management plans have been implemented for elasmobranch species in the Mediterranean and the current paper brings further evidence for a rapid implementation of the International Plan of Action for Conservation and Management of Sharks in the Mediterranean Sea.

\section{ACKNOWLEDGEMENTS}

The authors would like to thank the editor and the two anonymous referees, who consistently helped to improve the manuscript. This study was conducted in the framework of the EU Project EVOMED "The 20th Century evolution of Mediterranean exploited demersal resources under increasing fishing disturbance and environmental change" (Contract. N ${ }^{\circ}$ SI2 539097). Funding to G.C. Osio was provided by The Oak Foundation. The Authors are thankful to F. Ferretti for help in collecting "historic" trawl survey data.

\section{REFERENCES}

Baino R., Ligas A., Mancusi C., Reale B., De Ranieri S., Serena F. 2007. Catch composition and abundance of deep-sea elasmobranchs based on trawl surveys in Tuscany area. Biol. Mar. Mediterr. 14(2): 246-247.

Bartolino V., Colloca F., Sartor P., Ardizzone G.D. 2008. Modelling recruitment dynamics of hake Merluccius merluccius, in the central Mediterranean in relation to key environmental variables. Fish. Res. 93: 277-288.

Baum J.K., Myers R.A., Kehler D.G., Worm B., Harley S.J., Doherty P.A. 2003. Collapse and conservation of shark populations in the Northwest Atlantic. Science 299: 389-392.

Bishop J. 2006. Standardizing fishery-dependent catch and effort data in complex fisheries with technology change. Rev. Fish. Biol. Fisheries 16: 21-38.

Cardinale M., Linder M., Bartolino V., Maiorano L., Casini M. 2009. Conservation value of historical data: reconstructing stock dynamics of turbot during the last century in the KattegatSkagerrak. Mar. Ecol. Progr. Ser. 386: 197-206.

Cardinale M., Rätz H.J., Cheilari A. (eds.) 2010. Scientific, Technical and Economic Committee for Fisheries. Report of the 
SGMED-10-03 Working Group on the Mediterranean Part II. https://stecf.jrc.ec.europa.eu.

Cardinale M., Bartolino V., Llope M., Maiorano L., Sköld M., Hagberg J. 2011. Historical spatial baselines in conservation and management of marine resources. Fish Fisheries 12: 289-298.

Cartes J.E., Maynou F., Fanelli E., Papiol V., Lloris D. 2009. Longterm changes in the composition and diversity of deep-slope megabenthos and trophic webs off Catalonia (western Mediterranean): Are trends related to climatic oscillations? Prog. Oceanogr. 82: 32-46.

Cavanagh R.D., Gibson C. 2007. Overview of the Conservation Status of Cartilaginous Fishes (Chondrichthyans) in the Mediterranean Sea. IUCN, Gland, 42 pp.

Company J.B., Puig P., Sardà F., Palanques A., Latasa M., Scharek R. 2008. Climate Influence on Deep Sea Populations. PLoS ONE 3 (1): e1431. doi:10.1371/journal.pone.0001431.

Damalas D., Vassilopoulou V. 2011. Chondrichthyan by-catch and discards in the demersal trawl fishery of the central Aegean Sea (Eastern Mediterranean). Fish. Res. 108: 142-152.

Dell'Apa A., Kimmel D.G, Clo S. 2012. Trends of fish and elasmobranch landings in Italy: associated management implications. ICES J. Mar. Sci. 69(6): 1045-1052.

Ellis N., Wang Y.G. 2006. Effects of fish density distribution and effort distribution on catchability. ICES J. Mar. Sci. 64: 178-191

Ferretti F., Myers R.A., Sartor P., Serena F. 2005. Long term dynamics of the chondrichthyan fish community in the upper Tyrrhenian Sea. ICES CM 25: 1-34.

Ferretti F., Myers R.A., Serena F., Lotze H.K. 2008. Loss of large predatory sharks from the Mediterranean Sea. Conserv. Biol. 22(4): 952-964.

Ferretti F., Worm B., Britten G., Heithaus M.R., Lotze H.K. 2010. Patterns and ecosystem consequences of shark declines in the ocean. Ecol. Lett. 13: 1055-1071.

Fortibuoni T., Libralato S., Raicevich S., Giovanardi O., Solidoro C. 2010. Coding early naturalists' accounts into long-term fish community changes in the Adriatic Sea (1800-2000). PLoS ONE 5(11): e15502.

Frid A, Baker G.G., Dill L.M. 2008. Do shark declines create fear released systems? Oikos 117: 191-201.

Gasparini G.P., Ortona A., Budillon G., Astraldi M., Sansone E. 2005. The effect of the Eastern Mediterranean Transient on the hydrographic characteristics in the Strait of Sicily and in the Tyrrhenian Sea. Deep-Sea Res. I 52: 915-935.

Gouraguine A., Hidalgo M., Moranta J., Bailey D.M., Ordines F., Guijarro B., Valls M., Barberá C., De Mesa A. 2011. Elasmobranch spatial segregation in the western Mediterranean. Sci. Mar. 75(4): 653-664.

Ligas A., De Ranieri S., Micheli D., Reale B., Sartor P., Sbrana M. Belcari P. 2010. Analysis of the time series of landing and trawl survey data from the Tyrrhenian Sea (NW Mediterranean).
Fish. Res. 105: 46-56.

Lindebo E., Hoff A., Vestergaard N. 2007. Revenue-based capacity utilisation measures and decomposition: The case of Danish North Sea trawlers. Eur. J. Oper. Res. 180: 215-227.

Martin-Vide J., Lopez-Bustins J.A. 2006. The Western Mediterranean Oscillation and Iberian Peninsula Rainfall. Int. J. Climatol. 26(11): 1455-1475.

Maynou F., Sbrana M., Sartor P., Maravelias C., Kavadas S., Damalas D., Cartes J.E., Osio G.C. 2011. Estimating Trends of Population Decline in Long-Lived Marine Species in the Mediterranean Sea Based on Fishers' Perceptions. PLOS ONE 6(7): e21818.

Myers R., Worm B. 2003. Rapid worldwide depletion of predatory fish communities. Nature 423: 280-283.

Nezlin N.P., Lacroix G., Kostianoy A.G., Djenidi S. 2004. Remotely sensed seasonal dynamic of phytoplankton in the Ligurian Sea in 1997-1999. J. Geophys. Res. 109: C07013.

O’Neill M.F., Leigh G.M. 2007. Fishing power increases continue in Queensland's east coast trawl fishery Australia. Fish. Res. 85: 84-92.

Ordines F., Massutí E., Moranta J., Quetglas A., Guijarro B., Fliti K. 2011. Balearic Islands vs Algeria: two nearby western Mediterranean elasmobranch assemblages with different oceanographic scenarios and fishing histories. Sci. Mar. 75(4): 707-717.

Rijnsdorp A.D., Daan N., Dekker W. 2006. Partial fishing mortality per fishing trip: a useful indicator of effective fishing effort in mixed demersal fisheries. ICES J. Mar. Sci. 63: 556-566.

Sartor P. (coord.) (2011). The 20th Century evolution of Mediterranean exploited demersal resources under increasing fishing disturbance and environmental change (EVOMED, Contract. $\mathrm{N}^{\circ}$ SI2 539097). European Commission, Final Report, 515 pp.

Solow A.R. 1994. Detecting changes in the composition of a multispecies community. Biometrics 50: 556-565.

Stevens J.D., Bonfil R., Dulvy N.K., Walker P.A. 2000. The effects of fishing on sharks, rays, and chimaeras (chondrichthyans), and the implications for marine ecosystems. ICES J. Mar. Sci. 57: 476-494.

UNEP-MAP RAC/SPA 2005. Chondrichthyan fishes of Libya: Proposal for a research programme. Seret, B. Ed. RAC/SPA, Tunis, $31 \mathrm{pp}$.

van Oostenbrugge H.J.A.E., Powell J.P., Smit J.P.G., Poos J.J., Kraak S.B.M., Buisman E.F.C. 2008. Linking catchability and fisher behaviour under effort management. Aquat. Living Resour. 21: 265-273.

Zuur A.F., Ieno E.N., Smith G.M. 2007. Analysing Ecological Data. Springer, London, $680 \mathrm{pp}$.

Scient. ed.: P. Martin

Received May 14, 2012. Accepted October 11, 2012.

Published online January 21, 2013. 